ROCZNIKI PSYCHOLOGICZNE/ANNALS OF PSYCHOLOGY

2020, XXIII, 3, 291-307

DOI: https://doi.org/10.18290/rpsych20233-6

\author{
BOHDAN ROŻNOWSKI
}

John Paul II Catholic University of Lublin

\title{
ARE PROFESSIONAL BURNOUT AND WORK ENGAGEMENT OPPOSING OR INDEPENDENT CONSTRUCTS?
}

\begin{abstract}
The aim of the article is to broaden the knowledge about the mutual relationship between work engagement and professional burnout. In the psychological literature, a lively discussion between the position that these are opposite poles of one dimension and the position that both dimensions are independent has not yet been clearly concluded. The article focuses on the analysis of the causes of both phenomena. It was assumed that one-dimensionality means that the same elements of the work situation affect each of the states but in an opposite way. The research was conducted using standardized questionnaires (AWLS, LBQ, and UWES) on a group of 128 teachers from different types of schools. Statistical analyses relying on regression analysis indicated different sources of each phenomenon, which supports the position of independence of both constructs.
\end{abstract}

Keywords: burnout; work engagement; work-life areas.

The mutual relationship of work engagement and burnout is still the subject of heated debate in science to this day, although it has already taken about 15 years (Taris et al., 2017). It is still unclear whether these concepts are empirically and conceptually different or whether they constitute two faces of the same coin (Leon et al., 2015). It is important to stress that the discussion concerns both theoretical and empirical aspects. One issue (5) of the journal Burnout Research is entirely devoted to this subject (Schaufeli \& DeWitte, 2017). The crucial point in the editorial is: Is work engagement in contrast to burnout: real or redundant? In other words, are these constructs independent, or are they two opposite ends of a continuum that characterizes an employee's attitude to

Correspondence concerning this article can be sent to BOHDAN RożNOwSKI, PhD, Habil., Institute of Psychology, The John Paul II Catholic University of Lublin, Al. Racławickie 14, 20-950 Lublin, Poland; e-mail: bohroz@kul.pl; ORCID: https://orcid.org/0000-0002-2987-8234. 
his or her work? The collected material does not give a comprehensive answer. This is mainly because by concentrating on the analysis of relations between constructs, it emphasizes the comparison of outcomes, paying less attention to the causes of both phenomena.

\section{WORK ENGAGEMENT}

The understanding of work engagement has been dominated by the approach developed in Utrecht (Schaufeli \& Bakker, 2004), although there are also concepts from other researchers in the literature (Kahn, 1990). Work engagement is usually understood as a positive state of mind characterized by identification with the work being done and a high level of energy for work (Costa et al., 2016). Engaged employees are eager to invest a great amount of energy in their work and consider it sensible and worth being done well. This is mainly due to the labor resources to which the employee has access (Schaufeli \& Taris, 2014). In the study by Schaufelli et al. (2008), engagement was associated with demanding work, high levels of control, support from colleagues, job satisfaction, organizational commitment, good functioning in social relations, and low stress. Other studies have similar results (Baker, 2017; Baker \& Albrecht, 2018). Research on a Polish sample showed that there are specific factors that shape the attitude of engaged employees. According to the study, the most critical cognitive factor is the knowledge and acceptance of the goals of the work performed and the purposes of the organization. Another important factor in building work engagement are the rewards received by the employee, e.g., financial bonuses and development opportunities (Juchnowicz, 2010).

\section{BURNOUT}

Burnout is mainly defined as a state (Maslach \& Leiter, 2008). According to these researchers, the construct consists of three factors: exhaustion, distance to work, and a tendency to negatively assess the effects of one's work. Burnedout employees lack energy, they are cynical about their work (doubt its value) and may think that they are not successful. This results in a distance to work and therefore a lack of work engagement. Prolonged existence of this state in a longterm perspective leads to detrimental changes in the employee's well-being. The cause of burnout is stress, which can result from the accumulation of various 
sources related both to work itself and to the features of the organization. However, the most frequently cited are work overload and social conflict (Maslach et al., 2001) and a lack of adequate compensation for work (Siegrist, 2002).

A different approach was proposed by researchers based on the job demands-resources model (Demerouti et al., 2001). In their view, occupational burnout has two factors: exhaustion and disengagement. Each of them is a consequence of a different category of causes. Exhaustion is the result of high work demands, while disengagement is the result of insufficient resources. In the model of occupational burnout based on the analysis of requirements and resources, it was indicated that, among other factors, exhaustion is caused by Physical Workload, Time Pressure, Physical Environment, Recipient Contact, Shift Work; Disengagement is induced by Feedback, Rewards, Job Control, Participation, Security, Supervisor Support (Demerouti et al., 2001).

Schaufeli and Enzmann (1998) proposed an approach that integrates both approaches. They consider burnout to be a complex phenomenon that requires consideration of subjective, interpersonal, organizational, and social factors. Researchers assume that occupational burnout is a chronic negative mental state resulting from professional work. It manifests itself in exhaustion, discouragement, a decreased self-efficacy belief, falling achievement motivation, and an increase in negative attitudes and behaviors hindering effective job performance. The list of burnout symptoms was extended by Schaufeli and Enzmann. The Santinello study (2008) also shows more than three axial characteristics of occupational burnout. According to Schaufeli and Enzmann (1998), the source of occupational burnout is mainly a mismatch between individual aspirations and working conditions. This incompatibility may concern many different aspects of work. This requires one to observe as many of the work characteristics influencing the behavior of employees as possible (Morgeson \& Campion, 2002).

\section{WORK ENGAGEMENT AND BURNOUT RELATIONSHIP}

In the debate on the relationship between work engagement and burnout, the most frequently stressed aspect is the similarity in content between the descriptions of constructs; for example, Taris et al. (2017) claim that burnout and work engagement are to a large extent overlapping concepts and empirical differences should not be overestimated. 
Others point to systematic relationships between the two constructs revealed in a series of empirical studies. In all those studies, both constructs correlate negatively with each other at a statistically significant level, although at different strengths. However, some studies claim that work engagement completely overlaps with burnout (Cole et al., 2012), whereas others argue that both are negatively related but represent different concepts (Byrne et al., 2016). On the other hand, there are also voices in the discourse that emphasize the differences between the two constructs. Sonenetag (2017) claims that burnout is a chronic state that does not differ from one work task to the other or one day to another. Work engagement not only differs between persons and fluctuates from one day to another. It can also vary between different work tasks for the same person.

Demerouti and Bakker (2008) challenge Maslach's suggested similarity of concepts between burnout and loss of engagement. In their opinion, lack of engagement does not necessarily mean occupational burnout. Low involvement in the work may result from various causes and be a strategy to save resources, not necessarily leading to burnout. Furthermore, it is not easy to draw a line between non-engagement in work and a state of non-engagement that can already be regarded as a state of burnout. Therefore, Schaufeli and De Witte (2017) believe that occupational burnout and engagement have a two-factorial (two-dimensional) structure and constitute a separate dimension of professional activity.

Moreover, an important role in the discussion on the topic is the operationalization of both variables. Most studies on burnout use the Maslach Burnout Inventory (MBI; Maslach \& Jackson, 1981), whereas most studies on work engagement use the Utrecht Work Engagement Scale (UWES; Schaufeli et al., 2002). This means that the discussion about the relationship between the concepts of burnout and work engagement is narrowed to the discussion about the relationship between the instruments that measure burnout and work engagement (i.e., the MBI and the UWES). This is a limitation. Schaufeli and DeWitte (2017) conclude that up to now most research has either included only the three MBIsubscales (e.g., Leiter \& Maslach, 2016) or, even more narrowly, only the exhaustion-vigor and the cynicism-dedication dimensions of burnout and engagement (e.g., Mäkikangas et al., 2011). As Leiter and Maslach (2017) note, including all subscales simultaneously will reveal the dynamic nature of a wide range of possible psychological connections that employees have with their work. Scientifically speaking, this is a laudable goal.

To that end, I have designed a study focused on comparing the intensity of both structures and their conditions. This is consistent with the two aims of future research stated by Schaufeli and DeWitte (2017). The first postulates to 
include all subscales of the MBI and UWES simultaneously. It will provide a detailed picture of various ways employees connect psychologically with their work. The second is linked with the societal challenge. Burnout and work engagement should be studied to allow one to distinguish between burnout and non-burnout, low, average, or high in work engagement cases or occupation.

The one-dimensional relationship between two constructs is determined not only by the analogousness of the symptoms but also by the identity of the sources of the phenomena. On the contrary, constructs should interact, i.e., a given factor stimulates the syndrome from one extreme while simultaneously counteracting (suppressing) the disclosure of the other extreme. In the model presented by Demerouti et al. (2012), job requirements affect exhaustion of job resources and disengagement. Likewise, it has been shown that both these factors influence work engagement (Schaufeli \& Baker, 2004). On the other hand, some studies do not support this stance (Byrne et al., 2016). Thus, it is justified to ask the question whether work engagement and burnout will have a significant but opposing influence on the intensity level of these two constructs. On this basis, I proposed the following hypotheses:

\section{Hypothesis 1:}

Assessment of work resources will stimulate work engagement (is positively associated with) while negatively affecting the level of burnout (is negatively associated with)

\section{Hypothesis 2:}

The level of perceived work requirements will have a negative impact on work engagement and will have a positive effect on the level of occupational burnout

\section{Hypothesis 3:}

Both constructs, work engagement and burnout, are negatively correlated at the level of the global results and at the level of sub-dimensions.

To test the hypotheses, an empirical correlation study was conducted with the use of psychological questionnaires. Taking into account the opinion of Schaufeli and de Witte (2017) it was decided to avoid comparing MBI and UWES, the tools commonly used so far. 


\section{METHOD}

\section{Sample}

Based on a sample size calculator, ${ }^{1}$ I determined that the sample should include a minimum of 97 individuals. In the end, 150 people were invited, with 134 participating. As several questionnaires were largely incomplete, six respondents were excluded (4\%). The sample consists of 128 employees, with a prevalence of women $(82 \%, \mathrm{~W}: 105)$. However, the strong feminization of the teaching profession permits a conclusion that the proportions in the sample reflect the trend characteristic of the teacher population, where $79 \%$ are female according to Statistics Poland (Główny Urząd Statystyczny, 2018). The average age is 45 years $(S D: 6.96)$, ranging from 28 to 60 . The mean job tenure was 21 years $(S D: 8.18)$, and 15 for the current workplace ( $S D: 8.38)$. By type of school, the majority of teachers worked in primary schools $(30.5 \%)$, secondary schools (29.7\%), special schools (27.3\%), and vocational schools (12.5\%).

\section{Procedure}

The study was conducted from December 2017 to March 2018. The researcher distributed the questionnaires to the respondents during pedagogical meetings in individual schools and collected them at a predetermined date. The participants completed a set of questionnaires described in the measures section, as well as a short survey, including demographic variables (gender, age, school type, length of service). Participation in the study was voluntary and anonymous, which was confirmed with the subjects. Respondents were informed in a very general way about the purpose of the study, the rules for participation, providing at least verbal consent to participate in the study.

\section{Measures}

Work engagement. The variable of work engagement is most often operationalized in the literature through tools developed in Utrecht: a longer (17 items) and a shorter version (9 items) of the Utrecht Work Engagement Scale (UWES; Schaufeli \& Baker, 2003). A shorter version (see Schaufeli et al., 2006)

${ }^{1}$ For this, the A-Priori Sample Size Calculator for Multiple Regression (Soper, 2019) was used. The following assumptions were made: the desired power level $=.80 ; \alpha=.05$; the number of predictors is six, the anticipated effect size is medium (Cohen's $f^{2}=0.15$ ), based on literature reports. 
was chosen for the study due to better internal consistency on the Polish population $\left(\alpha=.92 ; \alpha_{\text {vigor }}=.79 ; \alpha_{\text {devotion }}=.92 ; \alpha_{\text {absorption }}=.92, \mathrm{~N}=1438\right.$; see Chirkowska-Smolak, 2012; Szabowska-Walaszczyk et al., 2011).

Burnout. Due to the objection that the study of the links between work engagement and burnout is instead a comparison of the results of the Maslachian and Leither method with Schaufelli's tool (Schaufeli \& DeWitte, 2017), a different questionnaire was chosen for the study: Massimo Santinello's Link Burnout Questionnaire (2010; Jaworowska, 2014).

The tool is used for surveying people working in the education and healthcare sectors. It rests on the assumption that the burnout results from excessive stress caused by a disturbance in the relationship between the working environment and the individual's resources, as set out by Maslach and Leither (2008). It focuses on four factors that make up the burnout symptom: psychophysical exhaustion $(\alpha=.77)$, lack of involvement in the customer relationship $(\alpha=.74)$, a sense of ineffectiveness $(\alpha=.67)$, disappointment $(\alpha=.86 ; N=995$; Jaworowska, 2014). Psychophysical exhaustion refers to the personal psychophysical resources which determine whether someone is full of tension, fatigue or, conversely, full of energy. Lack of involvement in the customer relationship refers to the description of the relationship between the respondent and the client (work), as marked by a negative attitude, hostility and reluctance in contact, or with an individual approach to the client and to commitment. A sense of professional ineffectiveness is linked to the subjective experience of lack of competences and low performance. Disappointment refers to the motivation to establish one's own career path.

According to the authors, people who perceive their profession as having a mission to do good may face a disappointing reality, which in turn will have a negative impact on enthusiasm and passion (Jaworowska, 2014). A review of the definition of factors indicates that the questionnaire makes it possible to measure both exhaustion and disengagement factors postulated in the job demands-resource model, which is particularly useful in this study.

Areas of Work Life. The Areas of Work Life Survey (AWLS), developed by Leither (2006), was chosen to measure the sources of work engagement and burnout. It is used to measure the subjective assessment of the functioning of the respondents and the needs resulting from their working environment. It can be used to estimate a mismatch, if any, between a person's capabilities and the requirements of their workplace that result in stress. The study used the Polish adaptation of the Canadian version of the tool developed at the Center for Organizational Research and Development (Terelak \& Izwantowska, 2009). The tool 
consists of 29 items which have been grouped into six factors: work overload $(\alpha=.80)$, control of work behavior $(\alpha=.70)$, satisfaction with rewards $(\alpha=.89)$, support from co-workers $(\alpha=.85)$, fairness $(\alpha=.87)$, values incongruence $(\alpha=.75 ; N=1492$; Terelak and Izwantowska, 2009). Work overload relates to the subjective assessment of the responsibilities being overwhelming or not. Control of work behavior includes the evaluation of one's own decision-making and autonomy at work. Satisfaction with the rewards beyond the assessment of satisfaction with financial compensation and the opportunity for promotion takes into account the appreciation and respect of other staff, management and mentorees. Support from co-workers includes an assessment of how other employees or supervisors can help, mutual cooperation, care, and constructive feedback. Fairness refers to the evaluation of the employee's sense of equality, fairness of treatment when being rewarded. Values incongruence refers to the assessment of the mismatch between the subjective values and those of the organization. All the above have been assigned to either work resources or work demands. Demands are work overload and values incongruence, and resources are control of work behavior, satisfaction with rewards, support from co-workers, and fairness.

\section{RESULTS}

\section{Preliminary Analysis}

To ensure the reliability of the results, data cleaning techniques were used. Given the hypotheses presented above, the data were checked for outliers using visual and quantitative methods (multivariate outliers' statistics for multiple linear regression, MLR). After a careful analysis of the scatterplots with outliers marked, no influential outliers were identified (Aguinis et al., 2013). No missing data were identified.

Harman's single-factor approach was used to test if the study is affected by Common Method Bias (CMB, Podsakoff et al., 2003). It requires that when including all studied variables in the unrotated explanatory factor analysis (EFA), one single factor should not appear as an optimal solution or, when fixed, one factor should not explain most of the covariance in the independent and dependent variables. The current study is not biased by CMB as EFA extracted 21 factors over eigenvalue equals one but also explained $28 \%$ of common variance with a single factor. 
Table 1. Descriptive Statistics and Intercorrelations of Studied Variables

\begin{tabular}{|c|c|c|c|c|c|c|c|c|c|c|c|c|c|c|c|c|c|c|}
\hline No. & Name & $M$ & $S D$ & $\alpha$ & 1 & 2 & 3 & 4 & 5 & 6 & 7 & 8 & 9 & 10 & 11 & 12 & 13 & 14 \\
\hline 1 & Work overload & 16.80 & 5.13 & .767 & 1 & & & & & & & & & & & & & \\
\hline 3 & Control of work behaviour & 11.12 & 2.77 & .729 & $-.51^{* *}$ & $-.63^{* *}$ & 1 & & & & & & & & & & & \\
\hline 4 & Satisfaction with rewards & 13.45 & 3.75 & .830 & $-.36^{* *}$ & $-.51^{* *}$ & $.59^{* *}$ & 1 & & & & & & & & & & \\
\hline 6 & Fairness & 18.67 & 5.05 & .827 & $-.47^{* *}$ & $-.72^{* *}$ & $.70^{* *}$ & $.66^{* *}$ & $.40^{* *}$ & 1 & & & & & & & & \\
\hline 7 & Vigor & 11.73 & 3.39 & .828 & $-.41^{* *}$ & $-.53^{* *}$ & $.34^{* *}$ & $.36^{* *}$ & $.43^{* *}$ & $.39^{* *}$ & 1 & & & & & & & \\
\hline 8 & Absorption & 11.84 & 3.39 & .675 & $-.23^{* *}$ & $-.41^{* *}$ & $.27^{* *}$ & $.25^{* *}$ & $.35^{* *}$ & $.20^{*}$ & $.67^{* *}$ & 1 & & & & & & \\
\hline 9 & Dedication & 13.53 & 2.71 & .711 & $-.26^{* *}$ & $-.37^{* *}$ & $.30^{* *}$ & $.37^{* *}$ & $.25^{* *}$ & $.32^{* *}$ & $.70^{* *}$ & $.69^{* *}$ & 1 & & & & & \\
\hline 13 & Sense of ineffectiveness & 13.83 & 4.60 & .698 & .14 & $.11^{* *}$ & $-.32^{* *}$ & $-.29^{* *}$ & $-.19^{*}$ & $-.24^{* *}$ & -.16 & -.04 & -.17 & -.13 & $.50^{* *}$ & $.48^{* *}$ & 1 & \\
\hline 14 & Disappointment & 15.97 & 6.02 & .821 & $.43^{* *}$ & $.39^{* *}$ & $-.38^{* *}$ & $-.39^{* *}$ & $-.40^{* *}$ & $-.45^{* *}$ & $-.54^{* *}$ & $-.33^{* *}$ & $-.43^{* *}$ & $-.49^{* *}$ & $.72^{* *}$ & $.65^{* *}$ & $.59^{* *}$ & 1 \\
\hline 15 & Burnout & 64.02 & 18.28 & .763 & $.46^{* *}$ & $.38^{* *}$ & $-.45^{* *}$ & $-.41^{* *}$ & $-.37^{* *}$ & $-.46^{* *}$ & $-.50^{* *}$ & $-.31^{* *}$ & $-.41^{* *}$ & $-.46^{* *}$ & $.86^{* *}$ & $.81^{* *}$ & $.75^{* *}$ & $.90^{* *}$ \\
\hline
\end{tabular}

Note. Composite scores are in boldface. $N=128$.

$* p<.05 . * * p .001$. 
Analyzing the above results, we see that vigor and mental exhaustion are negatively and strongly correlated $(r=-.57, p<.001$; Table 1$)$, while dedication is correlated moderately and negatively $(r=-.48, p<.001)$.

\section{Hypotheses Testing}

Hypothesis 1 (assessment of work resources is positively associated with work engagement but negatively with burnout) has been partially supported. First, the relationship between variables was studied at the concept level. Multiple linear regression (MLR) was calculated to predict work engagement and burnout based on assessment of work resources (Table 2). A regression equation was significant for both work engagement $\left(F(6,121)=8.66, p<.001 ; R_{\text {adj }}^{2}=.30\right)$ and burnout $\left(F(6,120)=9.56, p<.001 ; R^{2}\right.$ adj $\left.=.34\right)$.

Work resources (control of work behavior, satisfaction with the rewards, support from co-workers, fairness) are not correlated with any of the predictors.

Table 2. Multiple Regression Analysis of Overall Result of Burnout and Work Engagement by Areas of Work Life

\begin{tabular}{|c|c|c|c|c|c|c|c|c|c|c|}
\hline \multirow{2}{*}{ Variable } & \multicolumn{5}{|c|}{ Work engagement } & \multicolumn{5}{|c|}{ Burnout } \\
\hline & $B$ & $S E$ & $\beta$ & $t$ & $p$ & $B$ & $S E$ & $\beta$ & $t$ & $p$ \\
\hline Intercept & 46.55 & 8.01 & & 5.81 & .001 & 91.03 & 17.12 & & 5.32 & .001 \\
\hline Work overload & -1.37 & 1.28 & -.10 & -1.07 & .288 & 8.01 & 2.72 & .27 & 2.94 & .004 \\
\hline $\begin{array}{l}\text { Values } \\
\text { incongruence }\end{array}$ & -7.34 & 2.13 & -.42 & -3.45 & .001 & -3.88 & 4.54 & -.10 & -.85 & .395 \\
\hline $\begin{array}{l}\text { Control of } \\
\text { work behaviour }\end{array}$ & -0.56 & 1.54 & -.04 & -0.37 & .715 & -2.89 & 3.29 & -.10 & -.88 & .381 \\
\hline $\begin{array}{l}\text { Satisfaction } \\
\text { with rewards }\end{array}$ & 2.05 & 1.25 & .17 & 1.64 & .104 & -2.90 & 2.67 & -.11 & -1.09 & .279 \\
\hline $\begin{array}{l}\text { Support from } \\
\text { co-workers }\end{array}$ & 2.23 & 1.21 & .17 & 1.84 & .068 & -4.07 & 2.58 & -.14 & -1.58 & .117 \\
\hline Fairness & -2.25 & 1.92 & -.16 & -1.17 & .244 & -6.33 & 4.11 & -.20 & -1.54 & .126 \\
\hline$R^{2}$ adjusted & .30 & & & & & .34 & & & & \\
\hline$F$ & 8.66 & & & & & 9.56 & & & & \\
\hline$d f$ & 6 & & & & & 6 & & & & \\
\hline$p$ & .001 & & & & & .001 & & & & \\
\hline
\end{tabular}

Note. Demands: work overload, values incongruence; Resources: control of work behaviour, satisfaction with rewards, support from co-workers, fairness.

$N=128$. Statistically significant $p$ values are in boldface. 
Second, the relationship between variables was studied at the subscales level in the Santinello approach. MLR was calculated to predict subscales of work engagement and based on the assessment of work resources and demands (Table 3). A regression equation was significant for all components: vigor $(F(6,121)=$ $\left.=10.96, p<.001 ; R_{\text {adj }}^{2}=.35\right)$, dedication $\left(F(6,121)=4.58, p<.001 ; R_{\text {adj }}^{2}=.19\right)$, and absorption $\left(F(6,121)=5.88, p<.001 ; R^{2}{ }_{\text {adj }}=.23\right)$. Three resources are weakly and positively associated with work engagement subscales: satisfaction with the rewards with dedication $(\beta=.25, p=.028)$, fairness with absorption $(\beta=-.30, p=.037)$, support from co-workers with vigor $(\beta=.21, p=.018)$.

Table 3. Multiple Regression Analysis of Components of Work Engagement by Areas of Work

\begin{tabular}{|c|c|c|c|c|c|c|c|c|c|c|c|c|c|c|c|}
\hline \multirow{2}{*}{ Variable } & \multicolumn{5}{|c|}{ Vigor } & \multicolumn{5}{|c|}{ Dedication } & \multicolumn{5}{|c|}{ Absorption } \\
\hline & $B$ & $S D$ & $\beta$ & $t$ & $p$ & $B$ & $S E$ & $\beta$ & $t$ & $p$ & $B$ & $S E$ & $\beta$ & $t$ & $p$ \\
\hline Intercept & 16.25 & 3.09 & & 5.26 & .001 & 14.06 & 2.77 & & 5.08 & .001 & 16.24 & 3.38 & & 4.80 & .001 \\
\hline $\begin{array}{l}\text { Work } \\
\text { overload }\end{array}$ & -.97 & .49 & -.17 & -1.96 & .052 & -.29 & .44 & -.07 & -.66 & .508 & -.10 & .54 & -.02 & -.19 & .850 \\
\hline $\begin{array}{l}\text { Values } \\
\text { incongru- } \\
\text { ence }\end{array}$ & -2.82 & .82 & -.40 & -3.44 & .001 & -1.35 & .74 & -.24 & -1.83 & $.070^{\dagger}$ & -3.17 & .90 & -.45 & -3.53 & .001 \\
\hline $\begin{array}{l}\text { Control } \\
\text { of work } \\
\text { behaviour }\end{array}$ & -.67 & .60 & -.13 & -1.13 & .236 & -.05 & .53 & -.01 & -.09 & .926 & .16 & .65 & .03 & .24 & .811 \\
\hline $\begin{array}{l}\text { Satisfaction } \\
\text { with rewards }\end{array}$ & .52 & .48 & .11 & 1.08 & .280 & .96 & .43 & .25 & 2.22 & .028 & .56 & .53 & .12 & 1.06 & .290 \\
\hline $\begin{array}{l}\text { Support } \\
\text { from } \\
\text { co-workers }\end{array}$ & 1.12 & .47 & .21 & 2.41 & .018 & .15 & .42 & .03 & .35 & .724 & .95 & .51 & .18 & 1.87 & $.064^{\dagger}$ \\
\hline Fairness & -.28 & .74 & -05 & -.37 & .711 & -.27 & .67 & -.06 & -.40 & .690 & -1.71 & .81 & -.30 & -2.10 & .037 \\
\hline$R^{2}$ adjusted & 0.35 & & & & & 0.19 & & & & & 0.23 & & & & \\
\hline$F$ & 10.96 & & & & & 4.58 & & & & & 5.88 & & & & \\
\hline$d f$ & 6 & & & & & 6 & & & & & 6 & & & & \\
\hline$p$ & .001 & & & & & .001 & & & & & .001 & & & & \\
\hline
\end{tabular}

Note. Demands: work overload, values incongruence; Resources: control of work behaviour, satisfaction with rewards, support from co-workers, fairness.

$N=128$. Statistically significant $p$ values are in boldface.

$\uparrow p<.01$. 
Next, MLR was calculated to predict subscales of burnout and based on assessment of work resources (Table 4). A regression equation was significant for all burnout components: mental exhaustion $\left(F(6,121)=14.55, p<.001 ; R^{2}\right.$ adj $=$ $=.41)$, lack of commitment $\left(F(6,121)=3.62, p=.002 ; R^{2}{ }_{\text {adj }}=.15\right)$, feeling ineffective $\left(F(6,121)=3.46, p=.003 ; R_{\text {adj }}^{2}=.15\right)$, and disappointment $(F(6,121)=$ $\left.=8.88, p<.001 ; R^{2}{ }_{\text {adj }}=.31\right)$. Three components are weakly and negatively associated with burnout subscales: control of work behavior with feeling ineffective $(\beta=-.28, p=.030)$, support from co-workers with disappointment $(\beta=-.22$, $p=.018)$, and fairness with mental exhaustion $(\beta=-.32, p=.010)$. Satisfaction with the rewards is not significantly correlated with any of the burnout components.

Hypothesis 2 (the level of perceived work requirements will have a negative impact on work engagement and a positive impact on the level of occupational burnout) has been partially supported. First, the relationship between variables was studied at the concept level. Work overload is weakly and positively correlated with burnout ( $\beta=.27, p=.004$ ), while values incongruence is moderately and negatively associated with work engagement $(\beta=-.42, p<.001)$.

Second, the relationship between variables was studied at the subscales level in the Santinello approach. Work overload is weakly and negatively associated only with vigor $(\beta=-.17, p=.052)$. Values incongruence is moderately and negatively associated with vigor $(\beta=-.40, p<.001)$ and absorption $(\beta=-.45$, $p<.001)$. As regards burnout components, work overload is weakly and positively correlated with three components: mental exhaustion $(\beta=.36, p<.001)$, lack of commitment $(\beta=.27, p=.011)$, and disappointment $(\beta=.24, p=.011)$.

As one can see from the above results, the values incongruence is a universal factor because it relates to all aspects of work engagement in the Schaufeli and Bakker models. Other explanatory variables are important and specific to each dimension.

Hypothesis 3 (both work engagement and burnout are negatively correlated at the global and the factorial level) has been supported. Burnout and work engagement are correlated negatively and moderately at the level of general constructs $(r=-.46, p<.001)$. Vigor is negatively related with mental exhaustion $(r=-.57, p<.001)$, lack of commitment $(r=-.31, p<.001)$, and disappointment $(r=-.54, p<.001)$. Dedication is also negatively related with mental exhaustion $(r=-.48, p<.001)$, lack of commitment $(r=-.24, p<.001)$, and disappointment $(r=-.43, p<.001)$. Absorption is the most weakly related component and is negatively related with mental exhaustion $(r=-.43, p<.001)$ and disappointment $(r=-.33, p<.001)$, but not with lack of commitment $(r=-.17, p>.05)$. None of the work engagement predictors were significantly related to the burnout component of a sense of ineffectiveness ( $r$ from -.17 to $-.04, p>.05$ ). 
Table 4. Multiple Regression Analysis of Components of Burnout by Areas of Work

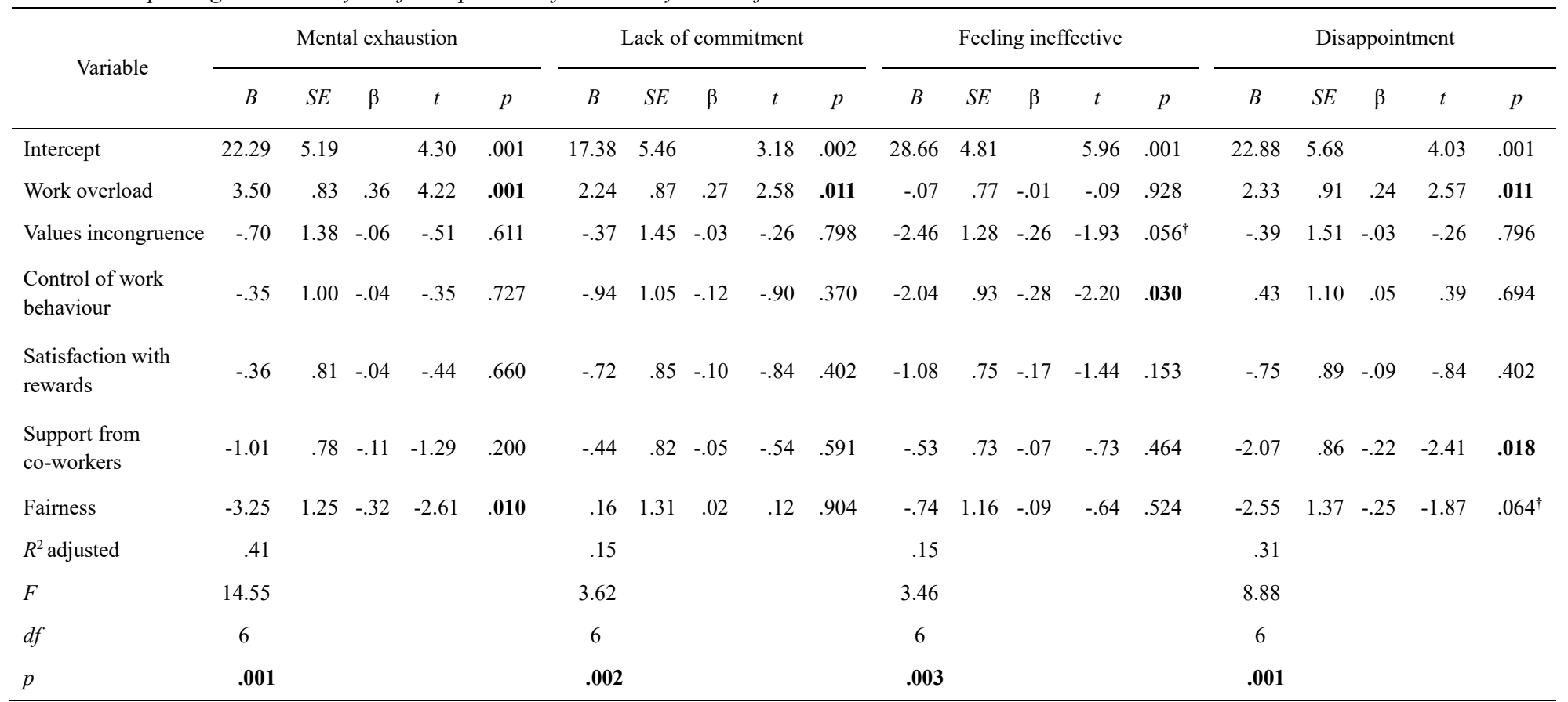

Note. Demands: work overload, values incongruence; Resources: control of work behaviour, satisfaction with rewards, support from co-workers, fairness. $N=128$. Statistically significant $p$ values are in boldface. $\dagger p<.01$. 


\section{DISCUSSION}

In light of the research conducted, we will conclude that both burnout and work engagement are not extremes of a single continuum. As the job demandsresources model suggests (Demerouti et al. 2001), the difference in causes, even if the symptoms are analogous, would require separating the two variables. Since other areas of work affect their extent, it is assumed that they can occur independently of each other. One can be burned out by excessive workload (which is a factor often indicated as a source of stress at work) and at the same time be stimulated to be engaged by own and the organization's values congruence.

The correlation sizes in the current study are similar to those other studies of the teaching population in Poland (Baka, 2015), which in turn illustrates the characteristic trend in the teaching profession.

Referring to the hypotheses, at a general level, work requirement-workload was positively associated with burnout while work resource-values congruence of employee and organization was positively associated with work engagement.

However, the research did not show any correspondence between work engagement and burnout - a positive effect on one variable did not mean a negative effect on the other variable at the same time. Therefore, it should be concluded that Hypotheses 1 and 2 have been partially supported. The workload [reversed] related to the employee's resources is only factor stimulating vigor (work engagement) and at the same time has a suppressive effect on the feeling of mental exhaustion (burnout). In this regard, it should also be noted that the correlation between vigor and exhaustion is the strongest among the correlations between all factors of both constructs. The correlation of the second pair of factors such as dedication and lack of commitment in the relationship also shows a statistically significant relationship, although it is not as strong as in the case of the previous pair. This argues for the independence of both concepts.

\section{LIMITATIONS}

Unfortunately, the study has some limitations. First, the size of the sample (120), despite being sufficient to obtain adequate statistical power of the test used, is relatively small. Second, Polish schools of vocational type are underrepresented among the respondents. That results mainly from the small share of these schools. Third, the study was limited to a group of teachers, but to be able to generalize the conclusions for the general population, other professional 
groups should also be studied. Only the confirmation of the presented results on other populations can be the basis for supporting the stance of independence of both constructs.

\section{REFERENCES}

Aguinis, H., Gottfredson, R. K., \& Joo, H. (2013). Best-practice recommendations for defining, identifying, and handling outliers. Organizational Research Methods, 16(2), 270-301. https://doi.org/10.1177/1094428112470848

Baka, Ł. (2015). Does job burnout mediate negative effects of job demands on mental and physical health in a group of teachers? Testing the energetic process of Job Demands-Resources model. International Journal of Occupational Medicine and Environmental Health, 28(2), 335-346. https://doi.org/10.13075/ijomeh.1896.00246

Bakker, A. B. (2017). Strategic and proactive approaches to work engagement. Organizational Dynamics, 46, 67-75. https://doi.org/10.1016/j.orgdyn.2017.04.002

Byrne, Z. S., Peters, J. M., \& Weston, J. W. (2016). The struggle with employee engagement: Measures and construct clarification using five samples. Journal of Applied Psychology, 101, 1201-1227. https://doi.org/10.1037/ap10000124

Chirkowska-Smolak, T. (2012). Psychologiczny model zaangażowania w prace [The psychological model of work engagement]. Wydawnictwo Naukowe UAM.

Cole, M. S., Walter, F., Bedeian, A. G., \& O’Boyle, E. H. (2012). Job burnout and employee engagement: A meta-analytic examination of construct proliferation. Journal of Management, 38, 1550-1581. https://doi.org/10.1177/0149206311415252

Colquitt, J. A., \& Zipay, K. P. (2015). Justice, fairness, and employee reactions. Annual Review of Organizational Psychology and Organizational Behavior, 2(1), 75-99. https://doi.org/10. 1146/annurev-orgpsych-032414-111457

Costa, P. L., Passos, A. M., \& Bakker, A. B. (2016). The work engagement grid: Predicting engagement from two core dimensions. Journal of Managerial Psychology, 31(4), 774-789. https://doi.org/10.1108/JMP-11-2014-0336

Demerouti, E., \& Bakker, A. B. (2008). Towards a model of work engagement. Career Development International, 13(3), 209-223. https://doi.org/10.1108/13620430810870476

Demerouti, E., Bakker, A. B., Nachreiner, F., \& Schaufeli, W. B. (2001). The job demandsresources model of burnout. Journal of Applied Psychology, 86(3), 499-512.

Główny Urząd Statystyczny (2018). Kobiety i mężczyźni na rynku pracy 2018 [Men and women on 2018 labor market]. Retrieved April 27, 2020, from https://stat.gov.pl/obszary-tematyczne/ rynek-pracy/opracowania/kobiety-i-mezczyzni-na-rynku-pracy-2018,1,7.html

Jaworowska, A. (2014). Kwestionariusz Wypalenia Zawodowego Massimo Santinello: polska normalizacja [Link Burnout Questionnaire by Massimo Santinello: Polish normalization]. Pracownia Testów Psychologicznych Polskiego Towarzystwa Psychologicznego.

Juchnowicz, M. (2010). Zarządzanie przez zaangażowanie. PWE.

Kahn, W. A. (1990). Psychological conditions of personal engagement and disengagement at work. The Academy of Management Journal, 33(4), 692-724. https://doi.org/10.2307/256287

Leiter, M. P. (2006). Areas of Worklife Survey Manual (4th ed.). Centre for Organizational Research \& Development. 
Leiter, M., \& Maslach, C. (2003). Areas of worklife: A structured approach to organizational predictors of job burnout. In P. Perrewe \& D. Ganster (Eds.), Research in Occupational Stress and Well Being (Vol. 3, pp. 91-134). https://doi.org/10.1016/S1479-3555(03)03003-8

Leiter, M. P., \& Maslach, C. (2016). Latent burnout profiles: A new approach to understanding the burnout experience. Burnout Research, 3(4), 89-100. https://doi.org/10.5465/256287

Leiter, M. P., \& Maslach, Ch. (2017). Burnout and engagement: Contributions to a new vision, Burnout Research, 5, 55-57. https://doi.org/10.1016/j.burn.2017.04.003

Leon, M. R., Halbesleben, J. R. B., \& Paustian-Underdahl, S. C. (2015). A dialectical perspective on burnout and engagement. Burnout Research, 2(2-3), 87-96. https://doi.org/10.1016/ j.burn.2015.06.002

Mäkikangas, A., Feldt, T., Kinnunen, U., \& Tolvanen, A. (2011). Do low burnout and high work engagement always go hand in hand? Investigation of the energy and identification dimensions in longitudinal data. Anxiety, Stress \& Coping, 25(1), 93-116. https://doi.org/ $10.1080 / 10615806.2011 .565411$

Maslach, C., \& Leiter, M. (2008). Early predictors of job burnout and engagement, Journal of Applied Psychology, 93(3): 498-512. https://doi.org/10.1037/0021-9010.93.3.498

Maslach, C., \& Jackson, S. E. (1981). The measurement of experienced burnout. Journal of Occupational Behavior, 2, 99-113. https://doi.org/10.1002/job.4030020205

Maslach, C., Schaufeli, W. B., \& Leiter, M. P. (2001). Job burnout. Annual Review of Psychology, 52, 397-422. https://doi.org/10.1146/annurev.psych.52.1.397

Morgeson, F. P., \& Campion, M. A. (2002). Minimizing tradeoffs when redesigning work: Evidence from a longitudinal quasi-experiment. Personnel Psychology, 55, 589-612.

Podsakoff, P. M., MacKenzie, S. B., Lee, J. Y., \& Podsakoff, N. P. (2003). Common method biases in behavioral research: a critical review of the literature and recommended remedies. Journal of Applied Psychology, 88(5), 879-903. https://doi.org/10.1037/0021-9010.88.5.879

Santinello, M. (2008). LBQ: link burnout questionnaire: manuale. Giunti O.S. Organizzazioni Speciali.

Santinello, M. (2014). LBQ. Kwestionariusz wypalenia zawodowego. Podręcznik [LBQ: Link burnout questionnaire: A manual]. Pracownia Testów Psychologicznych Polskiego Towarzystwa Psychologicznego.

Schaufeli, W., \& DeWitte, H. (2017). Outlook work engagement in contrast to burnout: Real and redundant! Burnout Research, 5, 58-60. http://doi.org/10.1016/j.burn.2017.06.002

Schaufeli, W. B., \& Enzman, D. (1998). The burnout companion to study \& practice. Taylor \& Francis.

Schaufeli, W. B., \& Bakker, A. (2003). Work Engagement Utrecht Scale. Preliminary manual. Utrecht University.

Schaufeli, W. B., \& Bakker, A. B. (2004). Job demands, job resources and their relationship with burnout and engagement: A multi-sample study. Journal of Organizational Behavior, 25, 293-315.

Schaufeli, W. B., Bakker, A. B., \& Salanova M. (2006). The measurement of work engagement with a short questionnaire. A cross-national study. Educational and Psychological Measurement, 66, 701-716.

Schaufeli, W. B., \& Taris, T. W. (2014). A critical review of the job demands-resources model: Implications for improving work and health. In G. F. Bauer \& O. Hämmig (Eds.), Bridging occupational, organizational and public health: A transdisciplinary approach (pp. 43-68). Springer. https://doi.org/10.1007/978-94-007-5640-3_4 
Schaufeli, W. B., Taris, T. W., \& Van Rhenen, W. (2008). Workaholism, burnout and work engagement: Three of a kind or three different kinds of employee well-being? Applied Psychology: An International Review, 57(2), 173-203. https://doi.org/10.1111/j.14640597.2007.00285.x

Siegrist, J. (2002). Effort-reward imbalance at work and health. In P. L. Perrewé \& D. C. Ganster (Eds.), Historical and current perspectives on stress and health (Vol. 2, pp. 261-291). Emerald.

Sonenetag, S. (2017). A task-level perspective on work engagement: A new approach that helps to differentiate the concepts of engagement and burnout. Burnout Research, 5, 12-20. https://doi.org/10.1016/j.burn.2017.04.001

Soper, D. S. (2019). A-priori sample size calculator for multiple regression [Computer software]. Retrieved November 5, 2019, from https://www.danielsoper.com/statcalc

Szabowska-Walaszczyk, A., Zawadzka A., \& Wojtaś, M. (2011). Zaangażowanie w pracę i jego korelaty: adaptacja skali UWES autorstwa Schaufeliego i Bakkera [Work engagement and its correlates: Adaptation of UWES by Schaufeli and Bakker]. Psychologia Jakości Życia, 10(1), $7-24$.

Taris, T. W., Ybema, J. F., \& van Beek, I. (2017). Burnout and engagement: Identical twins or just close relatives? Burnout Research, 5, 3-11. https://doi.org/10.1016/j.burn.2017.05.002

Terelak, J. F., \& Izwantowska, A. (2009). Adaptacja kwestionariusza Obszary Życia zawodowego (AWLS) Christiny Maslach i Michaela Leitera [Adaptation of AWLS by Christina Maslach and Michael Leiter]. Studia Psychologica UKSW, 9(4), 223-232. 